\title{
Restriction site heteroplasmy in the mitochondrial DNA of Brycon opalinus (Cuvier, 1819) (Characiformes, Characidae, Bryconiae)
}

A.W.S. Hilsdorf ${ }^{1,2}$ and J.E. Krieger ${ }^{1}$

\author{
${ }^{1}$ Laboratório de Genética e Cardiologia Molecular, INCOR, \\ Faculdade de Medicina, Universidade de São Paulo, São Paulo, SP, Brasil \\ ${ }^{2}$ Departamento de Fisiologia, Universidade Estadual de Campinas, Campinas, \\ SP, Brasil
}

\section{Correspondence}

A.W.S. Hilsdorf

Núcleo de Ciências Ambientais

Universidade de Mogi das Cruzes

Av. Dr. Cândido X.A. Souza, 200

08780-911 Mogi das Cruzes, SP

Brasil

Fax: +55-11-4798-7106

E-mail: wagner@umc.br

Research supported by FAPESP (No. 01/00009-0) and CNPq (No. 520696/95-6). A.W.S. Hilsdorf was the recipient of a Pre-Doctoral fellowship from CNPq.

Received April 10, 2003 Accepted November 18, 2003

\section{Introduction}

Mitochondrial DNA (mtDNA) has been a useful tool for population and evolution studies (1). Although attention has been focused on inter-individual variation, the nature and extent of intra-individual variation, or heteroplasmy of the mtDNA, cannot be ignored (2).

Homoplasmy is a feature usually found in the mtDNA of higher animal taxa (3). mtDNA polymorphism used in phylogeography and phylogeny analysis of related species is based on losses and gains of restric- tion sites by means of base substitution or insertion or deletion of a few base pairs (4). However, this polymorphism can also occur in the same organism due to mtDNA sequence differences. This phenomenon, known as heteroplasmy, consists of length or site variation, i.e., the presence of different mtDNA lengths or different nucleotide orders, respectively, in the same cell.

While site heteroplasmy is rare (5), length heteroplasmy is frequent in natural populations. Heteroplasmy seems to be related to length variants (6) and is commonly found in natural populations of fish, such as, shortnose 
sturgeon (7), sturgeon (8), percid fish species (9), brook stickleback (10), Atlantic cod (11), Walleye (12), and striped bass (13). Length heteroplasmy may arise from mechanisms of replication slippage, duplication or deletion and is frequently found in tandem repeated structures in the D-loop region (14).

Brycon is a genus comprising more than 60 neotropical species (15) distributed in Central and South America. We have previously analyzed $\mathrm{mtDNA}$ variability in natural and captive populations of Brycon opalinus (16). Data from RFLP analysis of B. opalinus populations demonstrated an unusual pattern of site heteroplasmy in samples from captive broodstock and from two rivers. Thus, in the present study we describe and report the frequency of mtDNA site heteroplasmy in populations of $B$. opalinus.

\section{Material and Methods}

A total of 257 specimens were sampled between 1997 and 1998 in the Paraíba do Sul basin located between the north of São Paulo State and the south of Rio de Janeiro State in southeastern Brazil. Wild populations were sampled from seven tributary rivers in the Paraibuna do Sul basin. A sampling of 80 individuals was taken from the broodstock of the Paraibuna Hydroelectric Power Company (CESP) Hatchery in the State of São Paulo.

Total DNA was extracted (17) from each individual and was screened by 24 restriction enzymes. The DNA fragments produced by the endonucleases were immobilized by Southern transfer (18) and the mtDNA frag-

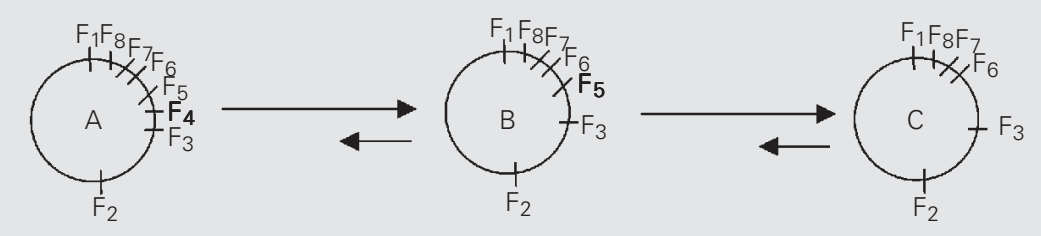

Figure 1. Three mutational patterns revealed by the endonuclease Nhel showing restriction site gains or losses. The pattern $A$ generates $B$ by loosing $F_{4}$ restriction site and $B$ generates $C$ by loosing $F_{5}$ restriction site. ments were detected by hybridization with $\left[\mathrm{P}^{32}\right]$-labeled homologous probes produced in our laboratory from B. opalinus mtDNA.

\section{Results and Discussion}

The presence of two mtDNAs of different lengths is common and may be the result of polymerase slippage in the repeat units during mtDNA replication. Intra-individual mtDNA differences at a single base are usually thought to be found in human diseases associated with mtDNA mutations (19).

Petri et al. (20) showed an extensive sequence heteroplasmy in the mtDNA control region from a European bat species whose mtDNA sequence variation within an individual was as high as that detected in the entire population. Intra-individual sequence variation has been observed in normal humans $(21,22)$ and in other mammals $(23)$. It seems that site heteroplasmy may be a principle, rather than an exception (24).

Few cases of restriction site heteroplasmy have been observed in fish. Bentzen et al. (25), using restriction enzyme analysis, assessed mtDNA variation in samples of American shad (Alosa sapidissima) captured in 14 rivers in Canada. The survey of the shad populations showed site heteroplasmy in ten individuals from different rivers, which indicated that this form of heteroplasmy might have originated more than once. Gold and Richardson (26) also produced evidence of site heteroplasmy in the marine species Sciaenops ocellatus. In the cited study one of 750 individuals showed site heteroplasmy involving the $N c o I$ and $X b a \mathrm{I}$ restriction enzymes. Brzuzan and Ciesielski (27), working on formalin-preserved individual of the species Coregonus albula from an extinct population, found nucleotide substitutions and site heteroplasmy compared to existing populations.

RFLP analysis of $B$. opalinus showed that six of 24 restriction enzymes were informative (ApaI, AvaII, EcoRI, HincII, HpaI 
and NheI) (16). The restriction enzyme NheI digestion revealed three different fragment patterns, NheI-A, NheI-B, and NheI-C, as a result of restriction site losses and gains. Pattern A originated pattern B by losing $\mathrm{F}_{4}$ and $\mathrm{B}$ originated $\mathrm{C}$ by losing $\mathrm{F}_{5}$. Thus, pattern $\mathrm{C}$ was possibly produced from pattern $\mathrm{A}$ by losing $\mathrm{F}_{4}$ and $\mathrm{F}_{5}$ (Figure 1).

Two of 80 samples of $B$. opalinus broodstock from the hydroelectric power plant hatchery showed a different pattern besides NheI-A, -B and -C. The two samples mentioned above showed both the NheI-A of $1180 \mathrm{bp}$ and NheI-B of $1260 \mathrm{bp}$ in the same individual (Figure 2). This new pattern was initially misinterpreted as a consequence of incomplete digestion by the NheI enzyme since there is no evolutionary explanation for the appearance of this fragment pattern and the sum of the bands exceeds the total mtDNA length of approximately $16,300( \pm$ $500) \mathrm{bp}$ in B. opalinus species. In order to determine if the appearance of fragments NheI-A and NheI-B in the same individual was a result of incomplete digestion, the samples were digested five times with larger quantities of the NheI restriction enzyme and the incubation time was prolonged. Even under these experimental conditions the resulting fragments continued to be the same, with the intensity of both bands remaining unchanged. In the case of incomplete digestion, a difference in intensity between the two fragments would be expected.

The site heteroplasmy observed in individuals of $B$. opalinus might have originated from a germ line cell through an independent mutational event followed by an incomplete segregation of the two fragments produced by the NheI endonuclease. Another possibility is the contribution of paternal mtDNA, as

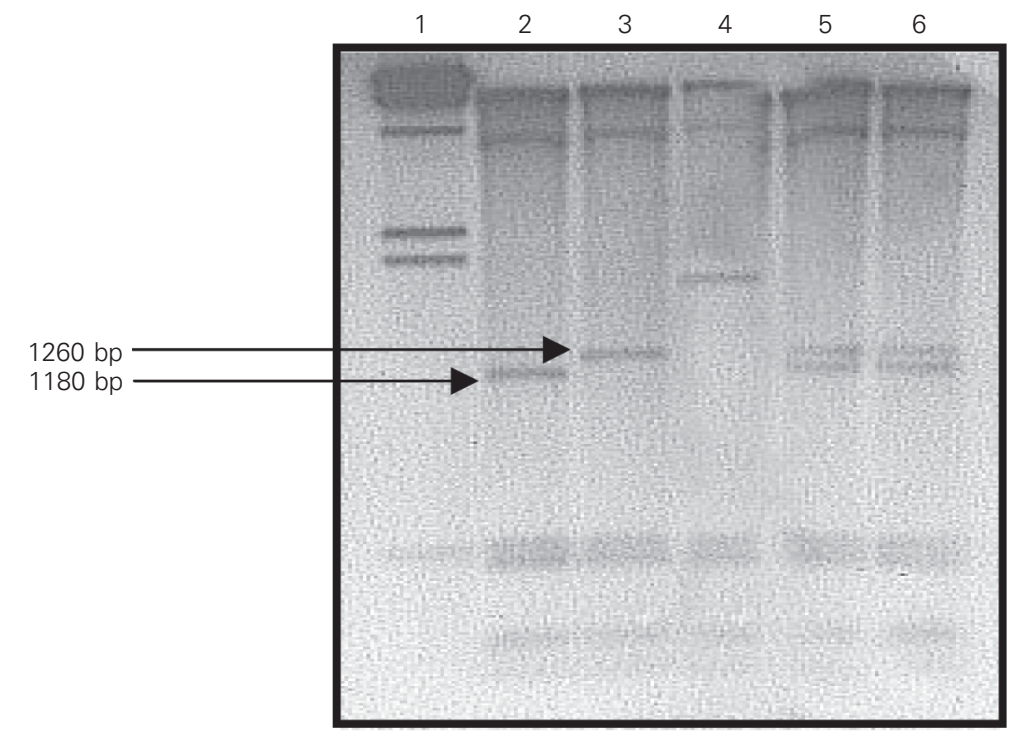

Figure 2. Restriction site heteroplasmy in Brycon opalinus mtDNA. Restriction fragment patterns obtained by Southern blotting from Nhel digestion. Lane 1 is the $\lambda$ Hindlll DNA marker. Lanes 2, 3 and 4 are the different fragment pattern of Nhel digestion. Individuals in lanes 5 and 6 are heteroplasmic for Nhel showing two classes (2 and 3 ) in the same individual.

observed in mussels (28) and mammals (29). This, however, may not be the case since the paternal mtDNA contribution is rarely fixed in the mtDNA present in an organism (30). According to Birky et al. (31), heteroplasmy is commonly found in germ line cells, and arises in somatic cells when more than one type of mtDNA molecule remains after embryonic development. The site heteroplasmy observed in the $B$. opalinus fish species, although restricted to a captive population, is further evidence of the occurrence of this phenomenon in lower vertebrate group.

\section{Acknowledgments}

We wish to thank Companhia Energética de São Paulo (CESP) and the staff of the Paraibuna Power Plant Hatchery for helpful assistance. 


\section{References}

1. Meyer A (1994). DNA technology and phylogeny of fish. In: Beaumont AR (Editor), Evolution of Aquatic Organisms. Chapman \& Hall, New York.

2. Stoneking M (1996). Mitochondrial DNA heteroplasmy: out of the closet. Biological Chemistry, 377: 603-604.

3. Brown WM (1985). The mitochondrial genome of animals. In: Maclntyre RJ (Editor), Evolutionary Genetics. Plenum Press, New York.

4. Avise JC \& Lansman RA (1983). Polymorphism of mitochondrial DNA in populations of higher animals. In: Nei M \& Koehn RK (Editors), Evolution of Genes and Proteins. Sinauer, Sunderland, MA, USA.

5. Moritz C, Dowling TE \& Brown WM (1987). Evolution of animal mitochondrial DNA: relevance for population biology and systematics. Annual Review of Ecology and Systematics, 18: 269-292.

6. Clark AG (1988). Deterministic theory of heteroplasmy. Evolution, 42: $621-626$

7. Grunwald C, Stabile J, Waldman JR, Gross R \& Wirgin I (2002). Population genetics of shortnose sturgeon Acipenser brevirostrum based on mitochondrial DNA control region sequences. Molecular Ecology, 11: 1885-1898.

8. Ludwig A, May B, Debus L \& Jenneckens I (2000). Heteroplasmy in the mtDNA control region of sturgeon (Acipenser, Huso and Scaphirhynchus). Genetics, 156: 1933-1947.

9. Nesbo CL, Arab MO \& Jakobsen KS (1988). Heteroplasmy, length and sequence variation in the mtDNA control regions of three percid fish species (Perca fluviatilis, Acerina cernua, Stizostedion lucioperca). Genetics, 148: 1907-1919.

10. Gach MH \& Brown WM (1987). Characteristics and distribution of large tandem duplications in brook stickleback (Culaea inconstans) mitochondrial DNA. Genetics, 145: 383-394.

11. Arnason E \& Rand DM (1992). Heteroplasmy of short tandem repeats in mitochondrial DNA of Atlantic cod, Gadus morhua. Genetics, 132: 211-220.

12. Billington N \& Hebert DN (1988). Mitochondrial DNA variation in great lakes Walleye (Stizostedion vitreum) populations. Canadian Journal of Fisheries and Aquatic Sciences, 45: 643-654.

13. Chapman RW (1987). Changes in the population structure of male striped bass, Morone saxatilis, spawning in the three areas of the Chesapeake Bay from 1984 to 1986. Fisheries Bulletin, 85: 167170.

14. Clayton DA (1991). Replication and transcription of vertebrate mitochondrial DNA. Annual Review of Cell Biology, 7: 453-478.

15. Howes G (1982). Review of the genus Brycon (Teleostei: Characoidei). Bulletin of the British Museum (Natural History). Zoology, 43: 1-47.

16. Hilsdorf AWS, Espin AMA, Krieger MH \& Krieger JE (2002). Mitochondrial DNA diversity in wild and captivity population of Brycon opalinus (Cuvier, 1819; Characiformes, Characidae, Bryconiae), in the Paraíba do Sul Basin, Brazil. Aquaculture, 214: 81-91.

17. Taggart JB, Hynes RA, Prodohl PA \& Fergusson A (1992). A simplified protocol for routine total DNA isolation from salmonid fishes. Journal of Fish Biology, 40: 963-965.

18. Sambrook J, Fritsch EF \& Maniatis T (1989). Molecular Cloning: A Laboratory Manual. 2nd edn. Cold Spring Harbor Laboratory, Cold Spring Harbor, New York.

19. Wallace DC (1995). Mitochondrial DNA variation in human evolution, degenerative disease, and aging. American Journal of Human Genetics, 57: 201-203.

20. Petri B, von Haeseler A \& Pääbo S (1996). Extreme sequence heteroplasmy in bat mitochondrial DNA. Biological Chemistry, 377: 661-667.

21. Comas D, Pääbo S \& Bertranpetit J (1995). Heteroplasmy in the control region of human mitochondrial DNA. Genome Research, 5 : 89-90.

22. Ivanov PL, Wadhams MJ, Roby RK, Holland MM, Weedn VW \& Parsons TJ (1996). Mitochondrial DNA sequence heteroplasmy in the Grand Duke of Russia Georgij Romanov establishes the authenticity of the remains of Tsar Nicholas II. Nature Genetics, 12: 417420.

23. Howell N, Halvorson S, Kubacka I, McCullough DA, Bindoff LA \& Turnbull DM (1992). Mitochondrial gene segregation in mammals: is the bottleneck always narrow? Human Genetics, 90: 117-120.

24. Grzybowski T (2000). Extremely high levels of human mitochondrial DNA heteroplasmy in single hair roots. Electrophoresis, 21: 548553.

25. Bentzen P, Leggett WC \& Brown GG (1988). Length and restriction site heteroplasmy in the mitochondrial DNA of American shad (Alosa sapidissima). Genetics, 118: 509-518.

26. Gold JR \& Richardson LR (1990). Restriction site heteroplasmy in the mitochondrial DNA of the marine fish Sciaenops ocellatus (L.). Animal Genetics, 21: 313-316.

27. Brzuzan P \& Ciesielski S (2000). Mitochondrial DNA sequence from an extinct population of European vendace, Coregonus albula (L.). Folia Biologica, 48: 151-154.

28. Zouros E, Freeman KR, Ball AO \& Pogson GH (1992). Direct evidence for extensive paternal mitochondrial DNA inheritance in the marine mussel Mytilus. Nature, 359: 412-414.

29. Gyllensten UB, Wharton D, Jossefsson A \& Wilson AC (1991). Paternal inheritance of mitochondrial DNA in mice. Nature, 352: 255-257.

30. Chapman RW, Stephens JC, Lansman RA \& Avise JC (1982). Models of mitochondrial DNA transmission genetics and evolution in higher eucaryotes. Genetics Research, 40: 41-57.

31. Birky CW, Maruyama T \& Fuerst $P$ (1983). An approach to population theory for genes in mitochondria and chloroplast, and some results. Genetics, 103: 513-527. 